International Journal of Pharmaceutics \& Pharmacology

Available Online: https://ijpp.edwiserinternational.com

\title{
Letter to Editor: Recent Advancement in Blood Cancer Research and Management
}

\author{
Jahangir $M A^{l}$ and Rao $A P^{2 *}$
}

${ }^{1}$ Department of Pharmaceutics, Nibha Institute of Pharmaceutical Sciences, Rajgir, Nalanda-803116, Bihar

${ }^{2}$ Clintech Solutions, Tirumala Complex, Dilsukh Nagar Main Road Hyderabad-500060, Telangana

\section{Letter to Editor}

Blood Cancer is one of the leading causes of death globally. As per National Foundation for Cancer Research 1.2 million people in the U.S alone is living with blood cancer [1]. According to the statistical data provided by Leukemia \& Lymphoma Society every 3 minutes a new person is diagnosed with some type of blood cancer [2]. Adding to the complexity of the disease there is no accurate survival data available. Generally, blood cancers are of three distinct types affecting the leucocyte cells (Leukemia), lymphocytes (Lymphoma) and plasma cells like B lymphocytes
(Myeloma). These are further sub-classified according to severity and effected cells. Recent advancements in diagnostic technique have significantly increased the survival rate.

Early diagnosis and staging of the disease play a pivotal role in blood cancer management and treatment strategies. Conventional methods include blood test, Bone marrow examination, Diagnostic imaging testsCT scan, PET scan, and X-ray, Physical examination, Surgical lymph node removal (for examination).

Table 1: Diagnostic technique for different types of blood cancers.

\begin{tabular}{|l|l|}
\hline \multicolumn{1}{|c|}{ Blood cancer sub-type } & \multicolumn{1}{|c|}{ Diagnostic technique } \\
\hline Acute myeloid leukemia & $\begin{array}{l}\text { Immunophenotyping, cytogenetics, molecular testing, Analysis of } \\
\text { FLT3, NPM1, and CEBPA, Analysis of PML-RARA }\end{array}$ \\
\hline Chronic myelogenous leukemia & $\begin{array}{l}\text { Cytogenetics, by FISH, or by PCR targeted at the BCR/ABL fusion } \\
\text { gene. }\end{array}$ \\
\hline Acute lymphoblastic leukemia & Immunophenotyping, bone marrow examination \\
\hline Chronic lymphocytic leukemia & $\begin{array}{l}\text { smears of the peripheral blood and bone marrow, } \\
\text { immunophenotyping, ZAP-70 analysis, and (Ig } \mathrm{V}_{\mathrm{H}} \text { ) gene mutation } \\
\text { status }\end{array}$ \\
\hline Polycythemia vera & $\begin{array}{l}\text { Molecular testing on a peripheral blood or bone marrow sample for } \\
\text { JAK2 V617F mutation }\end{array}$ \\
\hline Essential thrombocythemia & $\begin{array}{l}\text { Molecular testing on a peripheral blood or bone marrow sample for } \\
\text { JAK2 V617F mutation }\end{array}$ \\
\hline Primary myelofibrosis & $\begin{array}{l}\text { Molecular testing on a peripheral blood or bone marrow sample for } \\
\text { JAK2 V617F mutation }\end{array}$ \\
\hline Myelodysplastic syndromes & \begin{tabular}{l} 
cellularity, immunophenotyping, cytogenetics, and molecular studies \\
\hline
\end{tabular} \\
\hline
\end{tabular}

Staging helps understand the exact type, location, and spread of the cancer and it usually goes hand in hand with diagnosis. However, there are different advanced techniques for the detection of sub-types of blood 
cancers in a more accurate way. Table 1 summarizes the recent diagnostic methods for blood cancers [3]. In the recent past molecular level studies have gained pace. Many specific molecular markers are now known which helps in early detection of the disease. Some of specific molecular markers are listed in Table 2 [3]. However, many lymphomas have not yet been linked to any biomarker.

Table 2: Molecular markers for different types of blood cancers.

\begin{tabular}{|l|l|c|}
\hline \multicolumn{1}{|c|}{ Types of blood cancer } & \multicolumn{1}{c|}{ Detection of chromosome } & Markers \\
\hline Follicular lymphoma & $\mathrm{t}(14 ; 18)$ & IgH/BCL2 \\
\hline Mantle cell lymphoma & $\mathrm{t}(11 ; 14)$ & IgH/CCND1 \\
\hline Marginal zone lymphoma & $\mathrm{t}(11 ; 18)$ & API/MALT1 \\
\hline Burkitt lymphoma & $\mathrm{t}(8 ; 14)$ or $\mathrm{t}(2 ; 8)$ or $\mathrm{t}(8 ; 22)$ & IgH/CMYC \\
\hline Anaplastic large cell lymphoma & $\mathrm{t}(2 ; 5)$ & NPM/ALK \\
\hline
\end{tabular}

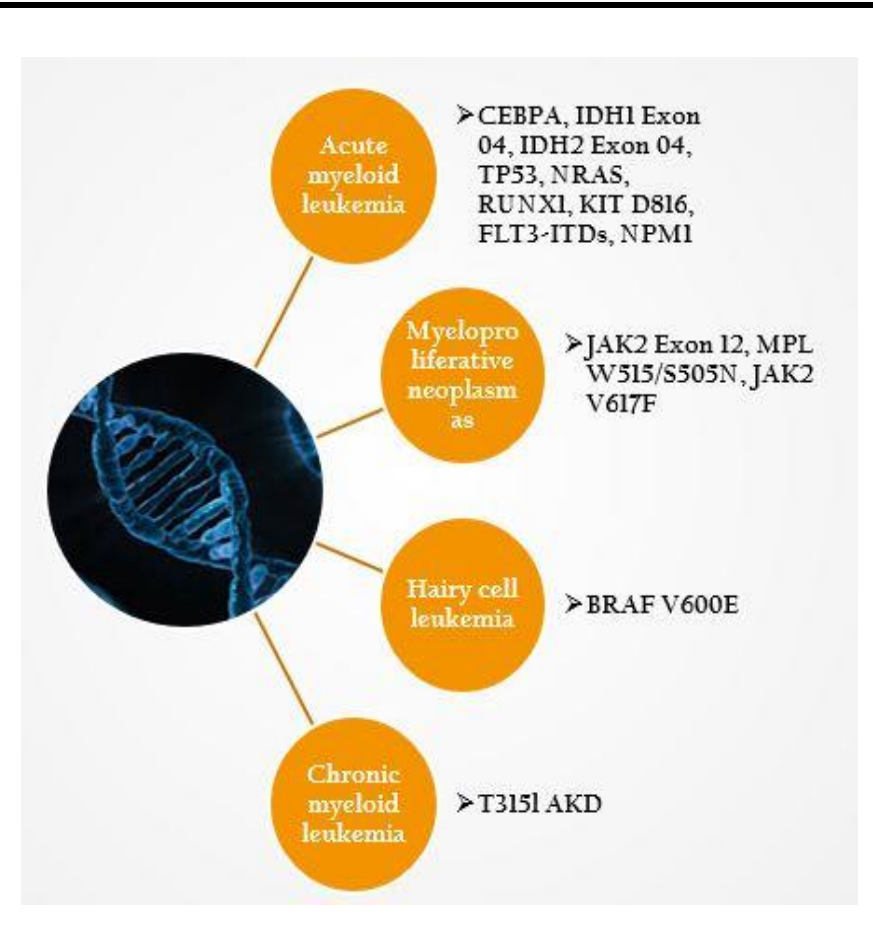

Figure 1: Genes associated with specific type of blood cancer.
Although there is no strong evidence of blood cancers being heritable in nature. Still several genes and their studies are being linked to specific type of blood cancers. They are now being exploited for molecular level diagnosis of the disease. Figure 1 shows different genes associated with specific type of blood cancer [3].

It is important that constant research should be performed to find novel ways for disease diagnosis and treatment. Although a number of conventional medication and treatment strategies is available in the market, many pharmaceutical companies are performing clinical trials and biomedical research in this regard. A number of drugs and biologicals have been approved by United Stated Food and Drug Administration (U.S.FDA) in the recent past. Table 3 summarizes the drugs approved by U.S.FDA in the last two years for blood cancers, the brand name, the company for which it has been approved and indication for medication [4].

Table 3: List of drugs approved by U.S.FDA for blood cancer in last two years.

\begin{tabular}{|l|c|l|l|c|}
\hline \multicolumn{1}{|c|}{ Drug } & Brand Name & \multicolumn{1}{|c|}{ Company } & \multicolumn{1}{|c|}{ Indication } & Year \\
\hline $\begin{array}{l}\text { Moxetumomab } \\
\text { pasudotox-tdf }\end{array}$ & Lumoxiti & $\begin{array}{l}\text { Astrazeneca } \\
\text { Pharmaceuticals }\end{array}$ & Hairy cell leukemia & 2018 \\
\hline $\begin{array}{l}\text { Gemtuzumab } \\
\text { ozogamicin }\end{array}$ & Tibsovo & Agios Pharmaceuticals & $\begin{array}{l}\text { CD33-positive acute myeloid } \\
\text { leukemia } \\
\text { myeloid leukemia }\end{array}$ & 2017 \\
\hline Ivosidenib & Rydapt & $\begin{array}{l}\text { Novartis } \\
\text { Pharmaceuticals } \\
\text { Corporation }\end{array}$ & $\begin{array}{l}\text { Acute myeloid leukemia with } \\
\text { genetic mutation of FLT3 }\end{array}$ & 2017 \\
\hline Midostaurin & Vyxeos & Jazz Pharmaceuticals & Acute myelogenous leukemia & 2018 \\
\hline $\begin{array}{l}\text { Daunorubicin and } \\
\text { cytarabine }\end{array}$ & & & Pfizer Inc & 2018 \\
\hline
\end{tabular}


Citation: Jahangir MA, Rao AP. Letter to Editor: Recent Advancement in Blood Cancer Research and Management. Int J Pharm Pharmacol 2019; 3: 135. doi: 10.31531/2581-3080.1000135

\begin{tabular}{|c|c|c|c|c|}
\hline Glasdegib & Daurismo & Pfizer Inc & $\begin{array}{l}\text { Newly diagnosed acute myeloid } \\
\text { leukemia }\end{array}$ & 2018 \\
\hline Gilteritinib & Xospata & Astellas Pharma & $\begin{array}{l}\text { Acute myeloid leukemia (AML) } \\
\text { with a FLT3 mutation }\end{array}$ & 2018 \\
\hline Enasidenib & Idhifa & Celgene Corporation & $\begin{array}{l}\text { Refractory acute myeloid } \\
\text { leukemia }\end{array}$ & 2017 \\
\hline Ivosidenib & Tibsovo & $\begin{array}{l}\text { Agios Pharmaceuticals, } \\
\text { Inc }\end{array}$ & $\begin{array}{l}\text { Refractory acute myeloid } \\
\text { leukemia }\end{array}$ & 2018 \\
\hline Blinatumomab & Blincyto & Amgen Inc & $\begin{array}{l}\text { B-cell precursor } \\
\text { lymphoblastic leukemia }\end{array}$ & 2018 \\
\hline Duvelisib & Copiktra & Verastem, Inc & $\begin{array}{l}\text { Refractory chronic lymphocytic } \\
\text { leukemia (CLL) or small } \\
\text { lymphocytic lymphoma (SLL) }\end{array}$ & 2018 \\
\hline Tisagenlecleucel & Kymriah & $\begin{array}{l}\text { Novartis } \\
\text { Pharmaceuticals } \\
\text { Corporation }\end{array}$ & $\begin{array}{l}\text { Young adult patients with a form } \\
\text { of acute lymphoblastic leukemia }\end{array}$ & 2017 \\
\hline Tagraxofusp-erzs & Elzonris & Stemline Therapeutics & $\begin{array}{l}\text { Blastic plasmacytoid dendritic } \\
\text { cell neoplasm }\end{array}$ & 2018 \\
\hline $\begin{array}{l}\text { Calaspargase pegol- } \\
\text { mknl }\end{array}$ & Asparlas & $\begin{array}{l}\text { Servier Pharmaceuticals } \\
\text { LLC }\end{array}$ & Acute lymphoblastic leukemia & 2018 \\
\hline Bosutinib & Bosulif & Pfizer Inc & \begin{tabular}{llr} 
Philadelphia & \multicolumn{2}{r}{ chromosome } \\
positive $\quad(\mathrm{Ph}+)$ & chronic \\
myelogenous leukemia & \\
\end{tabular} & 2017 \\
\hline Dasatinib & Sprycel & $\begin{array}{l}\text { Bristol-Myers Squibb } \\
\text { Co }\end{array}$ & $\begin{array}{l}\text { Philadelphia chromosome- } \\
\text { positive }(\mathrm{Ph}+) \text { chronic myeloid } \\
\text { leukemia }(\mathrm{CML})\end{array}$ & 2017 \\
\hline Venetoclax & Venclexta & $\begin{array}{l}\text { Abbvie Inc and } \\
\text { Genentech Inc. }\end{array}$ & $\begin{array}{l}\text { Chronic lymphocytic leukemia } \\
\text { (CLL) or small lymphocytic } \\
\text { lymphoma (SLL) }\end{array}$ & 2018 \\
\hline Nilotinib & Tasigna & $\begin{array}{l}\text { Novartis } \\
\text { Pharmaceuticals } \\
\text { Corporation }\end{array}$ & $\begin{array}{l}\text { Philadelphia chromosome } \\
\text { positive chronic myeloid } \\
\text { leukemia }\end{array}$ & 2018 \\
\hline $\begin{array}{l}\text { Rituximab and } \\
\text { hyaluronidase human }\end{array}$ & Rituxan hycela & Genentech Inc & $\begin{array}{l}\text { Follicular lymphoma, diffuse } \\
\text { large B-cell lymphoma, and } \\
\text { chronic lymphocytic leukemia }\end{array}$ & 2017 \\
\hline $\begin{array}{l}\text { Inotuzumab } \\
\text { ozogamicin }\end{array}$ & Besponsa & $\begin{array}{l}\text { Wyeth Pharmaceuticals } \\
\text { Inc., a subsidiary of } \\
\text { Pfizer Inc }\end{array}$ & $\begin{array}{l}\text { B-cell precursor } \\
\text { lymphoblastic leukemia }\end{array}$ & 2017 \\
\hline
\end{tabular}

From the patient's perspective, it is important that the financial burden of treatment must be minimized. In the coming years, we believe that more breakthrough researches will be made, and new and cost-effective way of treatment will be available for the masses.

\section{References}

1. National Foundation for Cancer Research. https://www.nfcr.org/blog/7-facts-need-knowblood-cancers/ accessed on $10^{\text {th }}$ May 2019.

2. Leukemia \& Lymphoma Society: Facts \& Statistics. https://www.lls.org accessed on $10^{\text {th }}$ May 2019.
3. Medical Laboratory Observer: Types of blood cancers-and the new molecular diagnostics. https://www.mloonline.com/home/article/13005498/types-of-bloodcancersand-the-new-molecular-diagnostics accessed on $10^{\text {th }}$ May 2019.

4. United States Food and Drug Administration: Drug Approvals and Databases. https://www.fda.gov/drugs/development-approvalprocess-drugs/drug-approvals-and-databases accessed on $10^{\text {th }}$ May 2019. 
Citation: Jahangir MA, Rao AP. Letter to Editor: Recent Advancement in Blood Cancer Research and Management. Int J Pharm Pharmacol 2019; 3: 135. doi: 10.31531/2581-3080.1000135

*Corresponding author: Dr. Rao AP, Technical Director, Clintech Solutions, Tirumala complex Dilsukh Nagar, Hyderabad-500060, Telangana; E-mail: paduman.bright@gmail.com
Article Info

Received 15 May 2019

Revised 07 June 2019

Published 28 June 2019

Copyright: (02019 Jahangir and Rao. This article is distributed under the terms of the Creative Commons Attribution 4.0 International License (http://creativecommons.org/licenses/by/4.0/), which permits unrestricted use, distribution, and reproduction in any medium, provided you give appropriate credit to the original author(s) and the source, provide a link to the Creative Commons license, and indicate if changes were made. 